\title{
Asteraceae Dumort nos campos rupestres do Parque Estadual do Itacolomi, Minas Gerais, Brasil: Barnadesieae e Mutisieae ${ }^{\mathbf{1}}$
}

Asteraceae Dumort in the rocky fields of the Parque Estadual do Itacolomi, Minas Gerais, Brazil: Barnadesieae and Mutisieae

\author{
Gracineide Selma Santos de Almeida ${ }^{2,3,5}$, Rita Maria de Carvalho-Okano ${ }^{2}$, Jimi Naoki Nakajima ${ }^{4}$ \\ \& Flavia Cristina Pinto Garcia ${ }^{2}$
}

\begin{abstract}
Resumo
O estudo das tribos Barnadesieae e Mutisieae é parte do levantamento florístico das espécies de Asteraceae nos campos rupestres do Parque Estadual do Itacolomi (PEI) em Minas Gerais, realizado através de coletas mensais no período de agosto de 2005 a agosto de 2007. Para as duas tribos foram identificadas 21 espécies pertencentes a seis gêneros: Dasyphyllum Kunth com quatro espécies e uma variedade; Chaptalia Vent.(quatro spp.), Gochnatia Kunth. (três spp.), Mutisia L.f. (uma spp.), Richterago Kuntze (seis spp.) e Trixis P. Br. (três spp.). Destas espécies, a maioria é restrita aos Campos Rupestres da Cadeia do Espinhaço ou áreas próximas com vegetação de transição, sendo quatro endêmicas de Minas Gerais. São apresentadas chaves de gêneros e espécies, descrições morfológicas, comentários taxonômicos, informações sobre a distribuição geográfica das espécies e ilustrações.
\end{abstract}

Palavras-chave: Asteraceae, Cadeia do Espinhaço, diversidade, florística, Minas Gerais

\begin{abstract}
The study of the tribes Barnadesieae and Mutisieae is part of the floristic inventory of Asteraceae species in the rocky fields (campos rupestres) of the Parque Estadual do Itacolomi (PEI) in Minas Gerais. The collections were carried out between in the period from August 2005 to August 2007. For the two tribes this study identified 21 species belonging to six generas: Dasyphyllum Kunth with four species and one variety; Chaptalia Vent. (four species), Gochnatia Kunth. (three species), Mutisia L.f. (one species), Richterago Kuntze (six species) and Trixis P. Br. (three species). Most of these species are restricted to the rocky fields of the Espinhaço Range or vegetated areas near the transition, being four endemic of the Minas Gerais states. Keys for the identification of genera and species, descriptions, taxonomic commentaries, information about the geographical distributions of species and illustrations are presented.
\end{abstract}

Key words: Asteraceae, Espinhaço Range, diversity, floristic, Minas Gerais.

\section{Introdução}

Asteraceae (Compositae) compreende 1.535 gêneros e 23.000 - 32.000 espécies amplamente distribuídas em todo o mundo (Pruski \& Sancho 2004). Apresenta-se organizada em três subfamílias: Barnadesioideae, Cichorioideae e Astereoideae e 17 tribos (Bremer 1994). Com base em dados filogenéticos Kadereit \& Jeffrey (2007), propõe a subdivisão da família em cinco subfamílias e 30 tribos. Entretanto, tendo em vista os inúmeros gêneros com posição incerta, a instabilidade desta classificação baseada em dados moleculares de um numero restritos de espécies, e sendo o Brasil muito diverso e rico em espécies endêmicas, a maioria delas ainda não incluídas neste estudo, optou-se por adotar a classificação de Bremer (1994). A família é basicamente caracterizada pela presença de inflorescência em capítulo, altamente modificada, ovário bicarpelar, ínfero e anteras sinânteras. Asteraceae encontra-se bem

\footnotetext{
${ }^{1}$ Parte da tese de Doutorado da primeira autora

${ }^{2}$ Universidade Federal de Viçosa, Depto. Biologia Vegetal, Campus Universitário, 36570-000, Viçosa, MG, Brasil.

${ }^{3}$ Universidade do Estado da Bahia, Depto. Ciências Exatas e da Terra, Campus II, BR 101, km 2, 48100-000, Alagoinhas, Bahia, Brasil.

${ }^{4}$ Universidade Federal de Uberlândia, Depto. Biociências, Uberlândia, MG, Brasil.

${ }^{5}$ Autora para correspondência: gracineide_almeida@yahoo.com.br
} 
representada em regiões tropicais, subtropicais e temperada, sendo mais abundante em formações campestres e montanhosas e menos frequente em formações florestais (Cronquist 1981). Na América tropical estima-se que existam aproximadamente 580 gêneros e 8.040 espécies (Smith et al. 2004). No Brasil a família encontra-se representada por 271 gêneros e 1.966 espécies, distribuídas por todo o país (Nakajima et al. 2010).

Barnadesieae é a única tribo da subfamília Barnadesioideae, apresenta nove gêneros e 92 espécies restritas a América do Sul, sendo o sudeste brasileiro centro de diversidade do maior gênero da tribo, Dasyphyllum (Bremer 1994). Estudos cladísticos elevaram a então subtribo Barnadesiinae de Mutisieae, a categoria de tribo em função de sua origem monofilética, sendo apontada como grupo-irmão do restante das Asteraceae (Bremer \& Jansen 1992). Diferencia-se, morfologicamente, de Mutisieae por apresentar ramos com espinhos axilares, corola densamente pilosa e papilho plumoso (Roque \& Pirani 1997).

Mutisieae pertence a sufamília Cichorioideae, compreende 76 gêneros e aproximadamente 970 espécies, ocorrendo nas regiões tropicais e subtropicais da África, Ásia, Austrália e no Havaí, predominando no Novo Mundo (Bremer 1994). Estudos filogenéticos têm demonstrado o polifiletismo da tribo, sendo as subtribos Gochnatiinae e Mutisiinae não monofiléticas, enquanto Nassauviinae é monofilética confirmando o posicionamento basal da maioria dos gêneros sul-americanos (Kim et al. 2002). A tribo é caracterizada pela presença de corola bilabiada com limbo anterior 3-lobado e posterior 2-lobado, anteras caudadas e estiletes com ramos glabros ou papilosos (Bremer 1994).

Trabalhos realizados vêm demonstrando a elevada diversidade florística de Asteraceae nos campos rupestres da Cadeia do Espinhaço (Giulietti et al. 1987; Hind 1995 2003; Roque \& Pirani 1997; Almeida \& Carvalho-Okano 2010). Por apresentarem uma expressiva diversidade de microambientes, estas áreas apresentam uma alto grau de endemismo e um grande número de plantas ainda não conhecidas, configurando como áreas de importância ecológica e de valor extremo (Costa et al. 1998; Zappi et al. 2003).

Os levantamentos florísticos do Parque Estadual do Itacolomi (PEI) (Badini 1939; Lisboa 1971; Peron 1989; Brandão et al. 1994; Messias et al. 1997), revelavam a representatividade da família Asteraceae nesta área. No entanto, era nítida a menor representatividade da família nestes levantamentos, evidenciada pelo número reduzido de espécies em tribos como Barnadesieae e Mutisieae, com gêneros endêmicos de campos rupestres. Tal fato é intensificado em se comparando com levantamentos realizados em outras áreas de campo rupestre da Cadeia do Espinhaço. Almeida (2008), ao realizar o levantamento florístico no PEI, amplia os dados para área com um quantitativo de 224 táxons de Asteraceae, tornando esta área, até então, como a de maior número de espécies desta família para o Brasil.

Neste trabalho é apresentado o levantamento florístico das espécies de Barnadesieae e Mutisieae (Asteraceae) nos campos rupestres do Parque Estadual do Itacolomi, além de chave analítica de identificação dos táxons, descrição, distribuição geográfica e ilustrações.

\section{Material e Métodos}

O Parque Estadual do Itacolomi (PEI) é uma unidade conservação criada pela Lei 4465 de 14 de Junho de 1967, ocupa área de cerca de 7.000 ha, nos municípios de Ouro Preto e Mariana em Minas Gerais, entre os paralelos $20^{\circ} 22^{\prime} 30^{\prime \prime}$ e $20^{\circ} 30^{\prime} 00^{\prime \prime}$ de latitude sul e os meridianos $43^{\circ} 32^{\prime} 30^{\prime \prime}$ e $43^{\circ} 22^{\prime} 30^{\prime \prime}$ de longitude oeste, abrangendo toda a Serra do Itacolomi (Peron 1989; Messias et al. 1997), compondo o limite sul da Cadeia do Espinhaço. A altitude varia de 1.100 a 1.772 m.s.m sendo o Pico do Itacolomi o ponto mais alto.

Os campos rupestres do PEI abrangem as áreas acima de 1.200 m.s.m, apresentando fitofisionomias diferenciadas em florestas estacionais, floresta de galeria, florestas nebulares, cerrado sensu stricto, campos rupestres quartziticos, campos rupestres com canga e campos limpos (Viana \& Lombardi 2007). O clima da região é caracterizado como de altitude, relativamente úmido, com nevoeiros frequentes e ventos dominantes na direção sudeste (Messias et al. 1997). A região da Cadeia do Espinhaço, apresenta clima mesotérmico (Cwb de Köppen), com verão suave, chovendo na estação quente; a estação chuvosa dura entre 7-8 meses, enquanto o período seco dura em média de 3-4 meses e coincide com o inverno (Giulietti et al. 1987).

Os solos são do tipo arenoso claro associado ao quartzito e do tipo argiloso com predomínio de latossolos vermelho-amarelos, podendo ser encontrados latossolos predominantemente em 
relevos ondulados e glainados e os litossolos em relevos mais escarpados. $\mathrm{Na}$ maioria das áreas o solo é raso, com pouca matéria orgânica sobre a rocha, rico em ferro e alumínio trocáveis, podendo haver áreas de solo inexistente (Benites et al. 2003).

As coletas do material botânico foram realizadas mensalmente com duração de três dias cada, no período de agosto de 2005 a agosto de 2007. O material coletado foi herborizado conforme as técnicas de Fidalgo \& Bononi (1984) e incorporado ao Herbário VIC, do Departamento de Biologia Vegetal da Universidade Federal de Viçosa. A identificação das espécies foi realizada por meio da literatura específica, comparações com coleções, através de consulta aos herbários OUPR, BHCB, SPF e RB e consulta a especialistas, quando necessário (acrônimos segundo Holmgren et al. 1990).

A classificação adotada para subfamílias, tribos e gêneros foi baseada em Bremer (1994). A terminologia utilizada para as descrições morfológicas está de acordo com Radford et al. (1974) e com a literatura taxonômica pertinente à família. As estruturas vegetativas e reprodutivas foram analisadas em estereomicroscópio e os detalhes florais foram analisados em capítulos conservados em solução de álcool a 70\%. As chaves de identificação e as descrições das espécies foram feitas de acordo com a variação morfológica dos exemplares coletados na área em estudo e examinados. As ilustrações foram confeccionadas com auxílio de câmara-clara acoplada a estereomicroscópio Zeiss, incluindo aspecto geral do ramo, bem como, as estruturas reprodutivas relevantes para identificação das espécies.

Os dados sobre a distribuição geográfica das espécies foram obtidos na literatura e nas etiquetas dos espécimes dos acervos consultados.

\section{Resultados e Discussão}

No PEI, para as duas tribos foram identificadas 21 espécies e uma variedade pertencentes a seis gêneros, estando Barnadesieae representada por Dasyphyllum Kunth com quatro espécies e uma variedade e Mutisieae representada por cinco gêneros: Richterago Kuntze com seis espécies, Chaptalia Vent. (quatro spp.), Gochnatia Kunth (três spp.), Trixis P. Br. (três spp.) e Mutisia L.f. com uma espécie. A diversidade no PEI se mostra maior em relação a outras áreas de campo rupestre da Cadeia do Espinhaço em Minas Gerais, tais como: Grão Mogol com oito espécies (Pirani et al. 2003); Serra do Cipó com 18 espécies a que se mostra mais similar (Giulietti et al. 1987) e Serra de Ouro Branco com seis espécies (Nahajima \& Hattori (com. pess.)). Estes dados reforçam a necessidade de conservação da área estudada e a identidade florística peculiar dos campos rupestres da Cadeia do Espinhaço.

Das espécies amostradas, apenas Chaptalia integerrima e $C$. nutans apresentam ampla distribuição, ocorrendo nas áreas de maior antropização. Chaptalia graminifolia, Gochnatia polymorpha e Richterago petiolata tiveram sua área de distribuição ampliada, sendo esta a primeira ocorrência destas espécies para Minas Gerais. Chaptalia martii, R. amplexifolia, R. campestris e $R$. polymorpha são até o momento, endêmicas de Minas Gerais. Na área de estudo, pode-se inferir que C. martii e Dasyphyllum fodinarum encontram-se ameaçadas extinção, uma vez que foram encontradas em populações pequenas e restritas a apenas uma ou duas áreas específicas.

\section{Tribo Barnadesieae}

Dasyphyllum Kunth, Nov. Gen. Sp. 4:17, t. 308. 1820

Arbustos eretos ou escandentes; espinhos axilares, geminados, retos ou recurvados. Folhas alternas, pecioladas. Capítulos solitários ou racemocorimbosos, terminais, homógamos. Invólucro campanulado, brácteas involucrais multisseriadas, imbricadas. Receptáculo plano, cerdoso ou cerdoso com páleas membranáceas. Flores numerosas hermafroditas, corola actinomorfa, pentalobada ou zigomorfa (pseudobilabiada); anteras oblongas com base sagitada e apêndice bilobado; ramos do estilete curtos, agudos, ápice papiloso. Cipsela obovóide denso velutina. Papilho plumoso.

\section{Chave para identificação das espécies de Dasyphyllum do Parque Estadual do Itacolomi}

1. Invólucro até $15 \mathrm{~mm}$ compr.; receptáculo com 8-12 páleas lineares Dasyphyllum flagellare

1. Invólucro de 25 - $35 \mathrm{~mm}$ compr.; receptáculo sem páleas.

2. Ramos com espinhos curtos $(2-4 \mathrm{~mm})$.

3. Capítulos pedunculados; flores com tubo externamente viloso Dasyphyllum fodinarum 
3. Capítulos sésseis; flores com tubo externamente glabro .... Dasyphyllum sprengelianum var. inerme 2. Ramos com espinhos longos $(6-18 \mathrm{~mm})$.

4. Espinhos retos; folhas com face abaxial glabra .... Dasyphyllum sprengelianum var. sprengelianum

4. Espinhos recurvados; folhas com face abaxial incano-velutinas ..... Dasyphyllum candolleanum

Dasyphyllum candolleanum (Gardner) Cabrera, Revista Mus. La Plata, Secc. Bot. 9 (38):86. 1959.

Fig. 1a

Arbusto ca. 1,5 m alt., ereto; ramos lenticelados, puberulentos; espinhos recurvados, longos, 10-18 mm compr. Folhas elípticas, 3-4,5 $\times 1,5-2 \mathrm{~cm}$, ápice apiculado, margem inteira, base atenuada, faces adaxial velutina, abaxial incano-velutina. Capítulos isolados, sésseis; invólucro 30-35 mm compr.; brácteas involucrais 7-8 séries, externas obovadas, glabras, margem ciliada, internas lanceoladas com dorso seríceo. Receptáculo com cerdas douradas. Flores 25-30, creme, corola tubulosa, $16-18 \mathrm{~mm}$, profundamente pentalobada, tubo glabro, lobos vilosos. Cipsela 7-9 mm compr., densamente albo-velutínea. Papilho 10-15 mm compr., castanho.

Material examinado: Mariana, PEI, Trilha do Sertão, 27.I.2006, fl. e fr., G.S.S. Almeida et al. 270 (VIC).

No Brasil esta espécie é encontrada nos estados de Pernambuco, Bahia, Distrito Federal, Goiás, São Paulo e Minas Gerais (Nakajima et al. 2010). No PEI encontra-se restrita a pequenas populações em campo graminoso seco. Distinguese de Dasyphyllum sprengelianum (Gardn.) Cabrera pelos espinhos recurvados e folhas com face abaxial incano-velutinas e de $D$. velutinum (Baker) Cabrera, a espécie mais próxima, pelo número menor de flores, e pelo indumento incanovelutino mais esparso em ambas as faces ou glabrescente na face adaxial das folhas. Segundo Hind (2003), a presença de corola com tubo longopubescente é a característica mais forte que separa $D$. velutinum de $D$. candolleanum, sendo este caráter mais consistente que aqueles propostos por Cabrera (1959).

Dasyphyllum flagellare (Casar.) Cabrera, Revista Mus. La Plata, Secc. Bot. 9(38): 60. 1959.

Fig. 1b-e

Arbusto ca. 2 m alt., escandente; caule puberulento, ramos jovens híspidos armados; espinhos recurvados, curtos 1,5-2 mm compr. Folhas oval-lanceoladas, 2-3,5 × 1-1,5 cm, ápice mucronado-espinhoso, margem inteira, base obtusa, face adaxial glabrescente, face abaxial esparsotomentosa com tricomas dourados. Capítulos 2-5 solitários, axilares, pedunculados; invólucro 13-15 mm compr.; brácteas involucrais 8-9 séries, ápice mucronado, margem ciliada, externas obovadas, albo-tomentosas na metade superior, internas lanceoladas, dourado-tomentosas. Receptáculo com cerdas douradas, $8-12$ páleas lineares. Flores 20-25, creme, tubulosas, $8-10 \mathrm{~mm}$, tubo glabro e lobos albo-tomentosos. Cipsela 2-2,5 mm compr., densamente albo-velutina. Papilho 7-9 mm comp., plumas com eixo dourado e glanduloso.

Material examinado: Ouro Preto, PEI, Trilha da Lagoa Seca, 27.VII.2006, fl. e fr., G.S.S. Almeida et al. 504 (VIC).

No Brasil Dasyphyllum flagellare é encontrada amplamente distribuída pela região sudeste, Goiás, Distrito Federal e Paraná (Nakajima et al. 2010). No PEI foi encontrada em populações pequenas, restritas a trilha da Lagoa Seca e a trilha da Casa do Bruno, ambas, em capão de mata de encosta seca. Esta espécie se diferencia das demais do gênero encontradas no PEI, pelo hábito arbustivo escandente e por apresentar invólucro menor (13-15 mm).

Dasyphyllum fodinarum (Gardner) Cabrera, Revista Mus. La Plata, Secc. Bot. 9(38): 84. 1959.

Fig. 1f-j

Arbusto ca. 1,2 m alt., ereto; caule puberulento, ramos jovens híspidos, armados; espinhos recurvados, curtos de 2-4 mm compr. Folhas oval-lanceoladas, 3-6 × 1-1,5 cm, ápice apiculado, margem inteira, base obtusa, quando jovem serícea em ambas as faces, quando adultas glabrescentes a glabras. Capítulos solitários ou 2-3 em racemos, pedunculados, envolvidos por um conjunto de folhas basais; invólucro 25-32 mm compr.; brácteas involucrais 8-9 séries, externas obovadas, ápice apiculado, margem ciliada, glabrescentes, internas lanceoladas, densamente seríceas. Receptáculo com cerdas douradas. Flores 25-30, creme, pseudobilabiadas, 18-22 mm, tubo e lobos vilosos. Cipsela 15-16 $\mathrm{mm}$ densamente albo-velutina. Papilho com plumas de eixo castanho-avermelhado. 


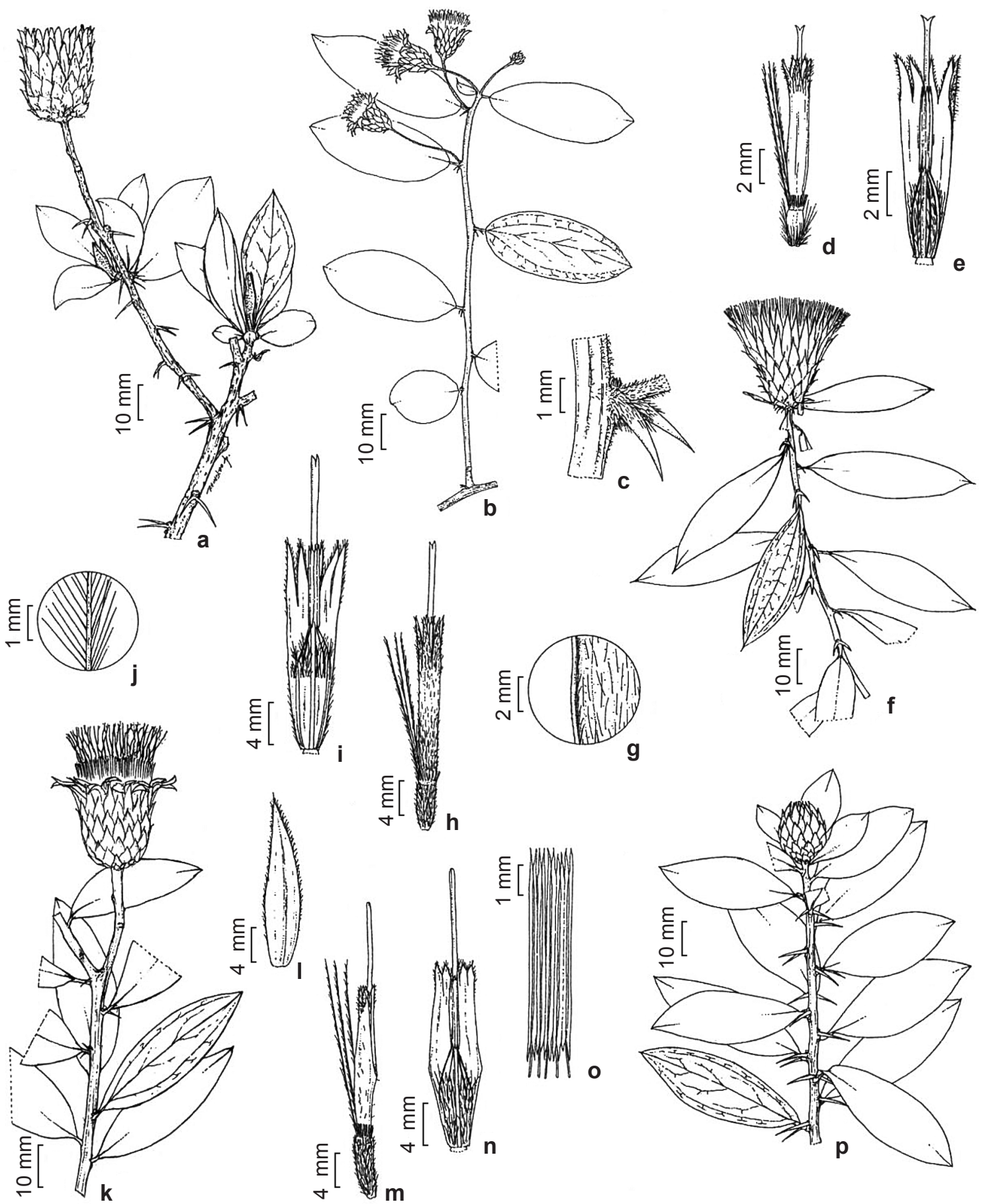

Figuras 1 - a. Dasyphyllum candolleanum - ramo (Almeida et al. 270). b-e. Dasyphyllum flagellare - b. ramo; c. espinhos; d. flor; e. abertura longitudinal da corola. (Almeida et al. 504). f-j. Dasyphyllum fodinarum - f. ramo; g. detalhe da folha; h. flor; i. abertura longitudinal da corola; j. cerda do papilho (Almeida et al. 386). k-o. Dasyphyllum sprengelianum var. inerme - k. ramo; 1. bráctea involucral; m. flor; n. corola em abertura longitudinal; o. anteras (Almeida et al. 410). p. Dasyphyllum sprengelianum var. sprengelianum - ramo (Almeida et al. 199).

Figures 1 - a. Dasyphyllum candolleanum - shoot (Almeida et al. 270). b-e. Dasyphyllum flagellare - b. shoot; c. thorns; d. floret; e. longitudinal opening of the corolla. (Almeida et al. 504). f-j. Dasyphyllum fodinarum - f. shoot; g. leaf of detail; h. floret; i. longitudinal opening of the corolla; j. pappus of bristles (Almeida et al. 386). k-o. Dasyphyllum sprengelianum var. inerme - k. shoot; 1. involucral bract; $\mathrm{m}$. floret; $\mathrm{n}$. longitudinal opening of the corolla; o. anthers (Almeida et al. 410). p. D. sprengelianum var. sprengelianum - shoot (Almeida et al. 199). 
Material examinado: Ouro Preto, PEI, Trilha da Estrada de Baixo, 23.VIII.2005, fl. e fr., G.S.S. Almeida et al. 66 (VIC); Trilha da Estrada de Cima, 19.IV.2006, fl. e fr., G.S.S. Almeida et al. 386 (VIC).

No Brasil Dasyphyllum fodinarum é encontrada apenas em Minas Gerais e São Paulo (Nakajima et al. 2010). No PEI foi encontrada em capão de mata de encosta, acima de 1300 m. Distingue-se de D. sprengelianum (Gardner) Cabrera, espécie mais próxima, pelos espinhos curtos (2-4 mm compr.), capítulos pedunculados e tubo da corola viloso.

Dasyphyllum sprengelianum var. inerme (Gardner) Cabrera, Revista Mus. La Plata, Secc. Bot. 9(38): 92. 1959.

Fig. 1k-o

Arbusto ca. 1,8 m alt., ereto, ramos glabros, lenticelados, inermes ou com espinhos curtos (2-4 mm) e caducos. Folhas elíptico-lanceoladas, $4-5,5 \times 1-1,5 \mathrm{~cm}$, ápice agudo às vezes obtuso, margem inteira, base atenuada, glabras. Capítulos solitários, sésseis; invólucro 25-30 mm compr.; brácteas involucrais 8-10 séries, margem ciliada, externas ovadas, internas lanceoladas, glabras, lustrosas. Receptáculo com cerdas douradas. Flores 48-50, amarelo-claras, tubulosas, 18-20 mm, tubo glabro, lobos longo-setosos. Cipsela 6-8 mm compr., densamente griseo-tomentosa. Papilho 15-18 mm compr., creme.

Material examinado: Mariana, PEI, Trilha da Serrinha, 30.V.2006, fl. e fr., G.S.S. Almeida et al. 410 (VIC).

No Brasil esta espécie é encontrada nos estados de Minas Gerais, São Paulo, Mato Grosso e Distrito Federal, Ceará, Pernambuco e Bahia (Nakajima et al. 2010). No PEI foram encontradas as duas variedades, sendo a var. sprengelianum encontrada em campo graminoso seco e a var. inerme na borda de capão de mata em vertentes no campo rupestre. Foi observado também que os indivíduos perdem completamente as folhas na estação seca, como mencionado por Roque \& Pirani (1997).

Dasyphyllum sprengelianum var. sprengelianum (Gardner) Cabrera, Revista Mus. La Plata,Secc. Bot. 9(38): 92. 1959.

Fig. $1 \mathrm{p}$

Arbusto ca. 1,5 m alt., ereto, ramos glabros, lenticelados, armados; espinhos retos, longos, 6-10 $\mathrm{mm}$ compr. Folhas elípticolanceoladas, 4-7 × 1,5-3 cm, ápice acuminado, margem inteira, base atenuada, quando adultas glabrescentes a glabras. Capítulos solitários, sésseis; invólucro 30-35 mm compr.; brácteas involucrais 10-12 séries, margem ciliada, externas ovadas, internas lanceoladas, glabras. Receptáculo com cerdas douradas. Flores 45-50, amarelo-claras, tubulosas, 18-20 $\mathrm{mm}$, tubo glabro, lobos longo-setosos. Cipsela 8-10 mm compr., densamente gríseo-tomentosa. Papilho 15-18 mm compr., creme.

Material examinado: Mariana, PEI, Trilha do Sertão, 2.XII.2005, fl. e fr., G.S.S. Almeida et al. 199 (VIC).

No Brasil esta variedade encontra-se distribuída pelos estados do Ceará, Pernambuco, Mato Grosso, Distrito Federal, Minas Gerais e São Paulo (Nakajima et al. 2010). Segundo Cabrera (1959), a var. sprengelianum é determinada pela presença dos espinhos longos e persistentes e das folhas com ápice acuminado, contrastando com a var. inerme com espinhos curtos, caducos e folhas de ápice obtuso. Dasyphyllum latifolium (Gardner) Cabrera é a espécie mais próxima, diferenciando-se principalmente pelas folhas mais largas, de ápice obtuso e base arredondada. Roque \& Pirani (1997) consideraram o tamanho do invólucro, o número de flores e a distribuição geográfica para distinguir as duas espécies.

\section{Tribo Mutisieae}

\section{Chave para identificação dos gêneros de Mutisieae do Parque Estadual do Itacolomi}

1. Planta ginodióica com tricomas do tipo " $T$ " Gochnatia

1. Planta ginomonóica sem tricomas do tipo "T"

2. Cipsela não-rostrada, cilíndrica ou oblonga

3. Planta volúvel; folhas pinaticompostas com gavinha terminal; papilho Mutisia

3. Planta ereta; folhas inteiras sem gavinha; papilho cerdoso.

4. Papilho basalmente conado em anel, persistente; flores alvas ou lilases ....... Richterago

4. Papilho livre, persistente ou caduco; flores amarelas .......................................... Trixis

2. Cipsela rostrada, raro atenuada no ápice Chaptalia 
Chaptalia Vent., Descr. Pl. Nouv. Jard. Cels: tab. 61. 1802.

Ervas perenes, ginomonóicas. Folhas rosulado-basais. Capítulos solitários. Invólucro campanulado, brácteas involucrais de 4-8 séries, imbricadas. Receptáculo plano, alveolado, glabro.
Flores trimorfas ou dimorfas: radiais femininas, bilabiadas; intermediárias femininas, liguladas ou curto-filiformes; centrais hermafroditas, tubulosas ou bilabiadas; anteras sagitadas na base, ápice agudo; ramos do estilete curtos, obtusos, papilosos. Cipsela fusiforme, 4-8 costada, rostrada. Papilho cerdoso.

\section{Chave para as espécies de Chaptalia do Parque Estadual do Itacolomi}

1. Folhas com face abaxial acastanhada; flores dimorfas Chaptalia martii

1. Folhas com face abaxial alva; flores trimorfas.

2. Folhas linear-lanceoladas; flores $35-40$ Chaptalia graminifolia

2. Folhas obovado-espatuladas ou lirado-pinatífidas; flores 100-220.

3. Folhas obovado-espatuladas; brácteas involucrais completamente verdes; flores 200-220, alvas ...... Chaptalia integerrima

3. Folhas lirado-pinatifidas; brácteas involucrais com ápice e margem vináceos; flores 100-150, róseas Chaptalia nutans

Chaptalia graminifolia (Dusén) Cabrera, Fl. Ilustr. Catar.,1 (Compositae tribe Mutisieae): 60. 1973.

Fig. 2a-e

Erva até $0,1 \mathrm{~m}$ alt. Folhas rosuladas, linearlanceoladas, 4-6 × 0,2-0,5 cm, ápice agudo, margem inteira, revoluta, base atenuada; face adaxial glabra, abaxial albo-tomentosa. Capítulo em escapo delgado, densamente albo-velutino; invólucro 10-15 mm compr.; brácteas involucrais 5-6 séries, lanceoladas, as externas vilosas, as internas glabras. Flores 35-40, brancas, trimorfas: radiais liguladas, $8-10 \mathrm{~mm}$, intermediárias curtoliguladas, 4-5 mm, centrais bilabiadas, 5-6mm. Cipsela 1,5-2 mm compr., 4-6 costada, glabra, glandulosa. Papilho 5-6 mm compr., cerdas alvas. Material examinado: Ouro Preto, PEI, Trilha da Lagoa Seca, 23.VIII.2005, fl. e fr., G.S.S. Almeida et al. 86 (VIC).

No Brasil, esta espécie é referida para os estados de São Paulo, Santa Catarina e Rio Grande do Sul (Nakajima et al. 2010). Esta é a primeira citação de ocorrência para o estado de Minas Gerais. No PEI, a espécie foi coletada em campo graminoso, próximo a afloramentos rochosos, em uma única trilha. Distingue-se de Chaptalia runcinata H.B.K., espécie mais próxima, pelas folhas maiores em comprimento, sempre inteiras e de consistência mais coriácea, além da cipsela curto-rostrada (Cabrera \& Klein 1973).

Chaptalia integerrima (Vell.) Burkart, Darwiniana 6: 576.1944.

Erva até $0,5 \mathrm{~m}$ alt. Folhas rosuladas, obovadoespatuladas, 9-13 × 1,5-3 cm, ápice mucronulado, margem inteira, base longamente atenuada; face adaxial glabrescente, abaxial densamente albotomentosa. Capítulo em escapo longo, avermelhado, alvo-tomentoso; invólucro $18-20 \mathrm{~mm}$; brácteas involucrais 6-8 séries, lineares, verdes, densamente tomentosas na face adaxial. Flores 200-220, alvas, trimorfas: radiais liguladas, $12-13,5 \mathrm{~mm}$; intermediárias curto-liguladas, 3,5-4 mm; centrais tubulosas, $11-15 \mathrm{~mm}$. Cipsela 10-12 mm compr., 5-costada, glabra, glandulosa. Papilho 10-12 mm compr., cerdas alvas.

Material examinado: Ouro Preto, PEI, Trilha da Estrada de Cima, 29.I.2006, fl. e fr., G.S.S. Almeida et al. 285 (VIC).

No Brasil, esta espécie apresenta ampla distribuição sendo considerada invasora (Leitão Filho 1975). No PEI foi coletado em área de grande influência antrópica. Chaptalia sinuata (Less.) Baker é a espécie mais próxima e diferencia-se por apresentar folhas com ápice obtuso e margem crenada ou denteada, flores femininas marginais liguladas com lábio interno bífido (Burkart 1944).

Chaptalia martii (Baker) Zardini, Darwiniana 19: 728. 1975. Fig. 2f-j

Erva até $0,3 \mathrm{~m}$ alt. Folhas rosuladas, elípticas, $2-5,5 \times 1-2,5 \mathrm{~cm}$, ápice obtuso, margem inteira ou esparsamente denticulada, base estreitamente atenuada; face adaxial albo-tomentosa, posteriormente glabra, abaxial densamente acastanhado-tomentosa. Capítulo ereto, algumas vezes pêndulo, escapo longo, alvo-tomentoso; invólucro $10-15 \mathrm{~mm}$; brácteas involucrais $3-4$ séries, lanceoladas, ápice acuminado, alvo- 


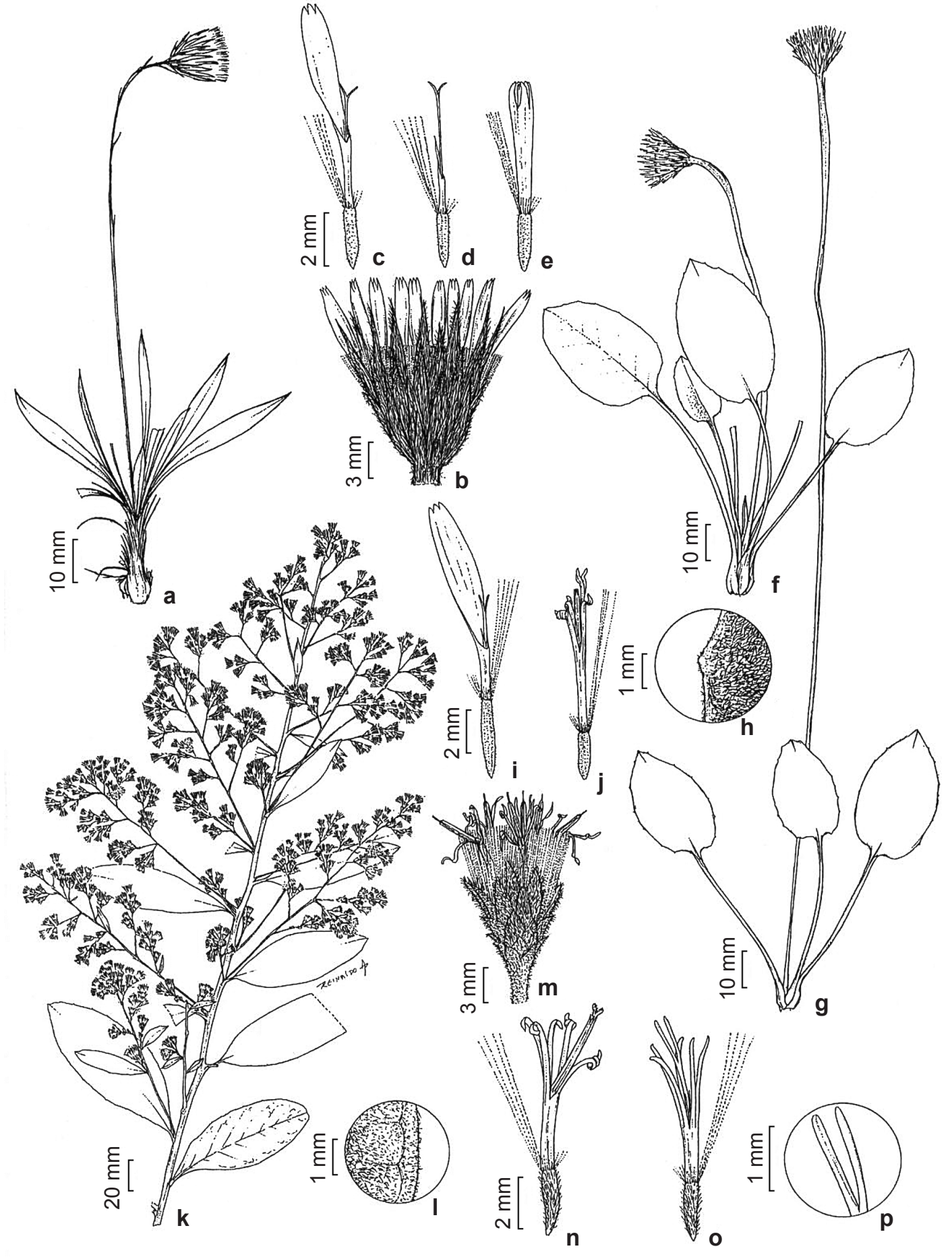

Figuras 2 - a-e. Chaptalia graminifolia - a. hábito; b. capítulo; c. flor do raio; d. flor intermediária; e. flor do disco (Almeida et al. 86). f-j. Chaptalia martii - f-g. hábito evidenciando a variação do escapo; h. margem foliar; i. flor radial; j. flor do disco (Almeida et al. 570). k-p. Gochnatia densicephala - k. ramo; 1. margem e face abaxial da folha; m. capítulo; n. flor hermafrodita; o. flor feminina; p. ramos do estilete da flor feminina (Almeida et al. 372). Figures 2 - a-e. Chaptalia graminifolia - a. habit; b. head; c. ray floret; $d$. intermediate floret; e. disc floret (Almeida et al. 86). f-j. Chaptalia martii - f-g. habit showing scape variation; h. leaf margin; i. ray floret; j. disc floret (Almeida et al. 570). k-p. Gochnatia densicephala - k. shoot; 1. margin and baxial leaf; m. head; $\mathrm{n}$. hermaphrodite floret; o. female floret; $\mathrm{p}$. style branches of female floret (Almeida et al. 372). 
tomentosas. Flores 35-40, róseas a alvas, dimorfas: radiais bilabiadas-liguliformes, $8-10 \mathrm{~mm}$; centrais bilabiadas, 7-8 mm, lábio interno bífido, revoluto. Cipsela 4-5 mm compr., 8-costada, esparsamente estrigosa. Papilho 5-6 mm compr., cerdas creme. Material examinado: Ouro Preto, PEI, Trilha da Lagoa Seca, 29.I.2007, fl. e fr., G.S.S. Almeida et al. 570 (VIC).

Chaptalia martii é restrita a Minas Gerais (Roque 2005). Na área de estudo a espécie foi encontrada em campo graminoso úmido em uma única trilha, em pequena população, o que a torna provavelmente ameaçada de extinção no PEI. Distingue-se de C. denticulata (Baker) Zardini pelas folhas elípticas, margem inteira ou quando denticuladas, sem dentes retrorsos. Segundo Roque \& Pirani (1997) a variação morfológica apresentada por C. martii, que pode apresentar folhas de margem denticulada, dificulta a identificação da espécie. No material coletado no PEI, foram encontradas tanto indivíduos com folhas de margem inteira, como indivíduos com margem denticulada (Fig. 22-24).

Chaptalia nutans (L.) Pol. Linnaea, 41: 582. 1877. Erva até 0,6 $\mathrm{m}$ alt. Folhas rosuladas, 9,5-20 $\times 3-4 \mathrm{~cm}$, lirado-pinatífidas, ápice agudo, margem espinhosa, base atenuada; faces adaxial glabra, abaxial densamente albo-tomentosa. Capítulo pêndulo, em escapo longo, aracnóide-lanoso a glabrescente; invólucro 20-25 mm; brácteas involucrais 4-5 séries, lanceoladas, margem e ápice vináceos, face adaxial albo-tomentosa. Flores 100-150, róseas, trimorfas: radiais liguladas, 10-12 $\mathrm{mm}$; intermediárias curto-filiformes, 5-6 mm; do disco tubulosas, 10-11 mm. Cipsela 12-14 mm comp., 5-costada, esparsamente estrigosa. Papilho 10-13 mm compr., cerdas alvas.

Material examinado: Ouro Preto, PEI, Trilha da Estrada de Baixo, 24.VIII.2005, fl. e fr., G.S.S. Almeida et al. 61 (VIC).

Chaptalia nutans apresenta ampla distribuição no Brasil, sendo encontrada nos estados de Mato Grosso, Rio de Janeiro, São Paulo, Paraná, Santa Catarina e Rio Grande do Sul (Cabrera \& Klein 1973); Bahia (Hind 1995); Minas Gerais, Pará, Goiás (Baker 1884) sendo considerada invasora (Leitão Filho 1975). No PEI a espécie foi coletada em área com grande influência antrópica na borda da trilha. Distingue-se da espécie mais próxima, $C$. integerrima (Vell.) Burk., pelas folhas lirado-pinatífidas.

Gochnatia Kunth, Nov. Gen. Sp. 4:19.1820.

Arbustos, ginodióicos; caule tomentoso com tricomas do tipo "T". Folhas alternas, pecioladas. Capítulos homógamos com flores hermafroditas ou funcionalmente femininas, sésseis a pedunculados, dispostos em panículas laxas ou densas. Invólucro campanulado; brácteas involucrais gradualmente maiores, imbricadas, lanceoladas, multisseriadas, tomentosas ou seríceas. Receptáculo alveolado. Flores creme, isomorfas, tubulosas, lobos lineares, longos, agudos, revolutos ou eretos; anteras caudadas, apêndice apical lanceolado, apiculado, base caudada, lisa ou laciniada; ramos do estilete obtusos. Cipsela cilíndrica. Papilho bisseriado com cerdas desiguais estrigosas, as maiores com ápice plumoso, creme.

\section{Chave para as espécies de Gochnatia do Parque Estadual do Itacolomi}

1. Capítulos sésseis a subsésseis, ordenados em panícula densa; brácteas involucrais glandulosas

1. Capítulos pedunculados, ordenados em panícula laxa; brácteas involucrais não glandulosas.

2. Face adaxial com tricomas birramosos e glandulares nas nervuras; pedúnculo bracteado G. pulchra

2. Face adaxial glabra, brilhante; pedúnculo não bracteado G. polymorpha

Gochnatia densicephala (Cabrera) Sancho, Novon 9(4): 559. 1999.

Fig. 2k-p

Subarbusto ca. $1,5 \mathrm{~m}$ alt.; ramos cinéreovelutinos. Folhas elípticas, 8,5-13,5 × 3-5,5 $\mathrm{cm}$, ápice agudo, às vezes apiculado, margem inteira, às vezes inconspicuamente denteada na metade superior, base atenuada; faces adaxial glabra, brilhante, abaxial densamente albo-vilosa. Capítulos sésseis ou subsséseis em panícula densa. Invólucro 8-10 mm; brácteas involucrais 4-5 séries, ápice agudo, margem ciliada, seríceas, glandulosas. Flores 12-14, hermafroditas, tubulosas, 7-8 $\mathrm{mm}$ lobos longos revolutos; anteras com apêndice basal longo-sagitado; ramos do estilete curtos, 
arredondados, lisos. Flores funcionalmente femininas 10-12, tubulosas, 5-6 mm, estaminóides presentes, hialinos; estilete longo exserto, ramos curtos, triangulares, patentes. Cipsela 2,5-3 mm compr., vilosa. Papilho 4-6 mm compr.

Material examinado: Ouro Preto, PEI, Trilha da Lagoa Seca, 24.VIII.2005, fl. e fr., G.S.S. Almeida et al. 88 (VIC); Trilha do Calais, 17.IV.2006, fl. e fr., G.S.S. Almeida et al. 372 (VIC); Trilha da Casa do Bruno, 18.IV.2006, fl. e fr., G.S.S. Almeida et al. 383 (VIC). Mariana, PEI, Trilha da Serrinha, 29.VIII.2006, fl. e fr., G.S.S. Almeida et al. 513 (VIC).

Gochnatia densicephala é endêmica do Brasil e encontra-se distribuída pelos estados de Minas Gerais, Rio de Janeiro, São Paulo, Distrito Federal e Bahia (Nakajima et al. 2010). Frequentes em campos de cerrado, em morros ou serras com altitude superior a $1100 \mathrm{~m}$. (Sancho 2000). No PEI a espécie foi encontrada em campos de afloramentos rochosos. Distingue-se de Gochnatia paniculata (Less.) Cabrera, espécie mais próxima, pelas folhas glabras na face adaxial e capítulos sésseis. G. floribunda Cabrera é outra espécie semelhante, mas se diferencia por apresentar capítulos pedunculados, além de brácteas involucrais glabras ou apenas ciliadas.

Gochnatia polymorpha (Less.) Cabrera, Not. Mus. La Plata 15: 43. 1950.

Arbusto ca. 2 m alt., ramos cinéreotomentosos. Folhas oblongo-lanceoladas, 11,5-15 $\times 2,5-5 \mathrm{~cm}$, ápice acuminado, margem inteira, às vezes denteada, base arredondada a subcordada; faces adaxial glabra, brilhante, abaxial densamente flocosa. Capítulos pedunculados, pedúnculo não bracteado, dispostos em panícula folhosa laxa; invólucro $8-10 \mathrm{~mm}$; brácteas involucrais $4-5$ séries, ápice agudo, margem ciliada, dorsalmente tomentosas. Flores 8-15, hermafroditas, tubulosas, 7-9 mm, lobos levemente revolutos no ápice; anteras com base caudada, laciniada; ramos do estilete curtos, glabros. Flores funcionalmente femininas não vistas. Cipsela 2,5-3 mm compr., densamente setosa. Papilho 5-7 mm compr.

Material examinado: Ouro Preto, PEI, Trilha da Estrada de Cima, 28.IX.2005, fl. e fr., G.S.S. Almeida et al. 132 (VIC); Trilha do Calais, 31.IV.2006, fl. e fr., G.S.S. Almeida et al. 424 (VIC); Trilha da Lagoa Seca, 26.VI.2006, fl. e fr., G.S.S. Almeida et al. 442 (VIC).

Gochnatia polymorpha ocorre nos estados de Minas Gerais, Santa Catarina, São Paulo, Paraná e Rio Grande do Sul (Cabrera \& Klein 1973); Bahia, Espírito Santo, Goiás, Mato Grosso do Sul e Rio de Janeiro (Sancho 2000). No PEI a espécie foi coletada em áreas de transição entre campo rupestre e florestas estacionais semideciduais e em campos rupestres. Gochnatia paniculata (Less.) Cabrera, é a espécie mais próxima de G. polymorpha, diferenciando-se basicamente pelo hábito arbóreo e folhas ovado-lanceoladas, característico da última (Roque \& Pirani 1997). No PEI apresenta hábito arbustivo, entretanto a variação no hábito das espécies de campos rupestres é comum, em decorrência do estresse constante. Algumas espécies que em outros ambientes atingem o hábito arbóreo, no campo rupestre adquirem o hábito arbustivo. Sancho (2000) cita onze espécies da sect. Moquiniastrum, dentre elas G. polymorpha, como heliófitas que habitam os campos de cerrado e salienta que fatores limitantes próprios deste ambiente, poderiam conduzir a modificações morfoestruturais.

A presença de capítulos pedunculados em $G$. polymorpha e capítulos sésseis em G. paniculata, permite a distinção mais precisa entre essas espécies.

Gochnatia pulchra Cabrera, Revista Mus. La Plata, Secc. Bot. 12(66): 106. 1971.

Arbusto ca. 1,8 m alt.; ramos cinéreotomentosos, quando jovens alvo-tomentosos. Folhas elípticas, 7,5-9 × 2,5-4,5 cm, ápice agudo, às vezes obtuso, margem inteira, às vezes denteada na metade superior, base cuneada; faces adaxial glabrescente com tricomas birramosos, glandulares, concentrados nas nervuras, abaxial densamente albo-tomentosa, com nervuras proeminentes, cinéreas. Capítulos pedunculados, pedúnculo bracteado, em panícula folhosa laxa; invólucro 7-10 $\mathrm{mm}$; brácteas involucrais 4-5 séries, ápice agudo, densamente lanosas. Flores 10-12, hermafroditas, tubulosas, $8-10 \mathrm{~mm}$, lobos longos, revolutos; anteras com apêndice basal levemente laciniado; ramos do estilete curtos, arredondados, lisos. Flores funcionalmente femininas não vistas. Cipsela 2,5-3 mm compr., densamente cinéreoserícea. Papilho 5-7 mm comprimento.

Material examinado: Ouro Preto, PEI, Trilha da Casa do Bruno, 18.IV.2006, fl. e fr., G.S.S. Almeida et al. 379 (VIC).

Gochnatia pulchra encontra-se distribuída no Brasil, pelos estados de Minas Gerais, Goiás, Distrito Federal e São Paulo (Nakajima et al. 2010). Frequentes em zonas altas de campos de cerrado, em vegetação aberta com solos de areia fina com pouca argila em altitude superior a $1100 \mathrm{~m}$ (Sancho 2000). No PEI foi coletada em campos de 
afloramento rochosos. Distingue-se da espécie mais próxima G. floribunda Cabrera, pelos capítulos mais laxos, pedúnculos bracteados e brácteas densamente lanosas.

Mutisia L.f., Suppl. Plant.: 57:373.1781.

Arbusto volúvel, monóicos; caule tomentoso. Folhas alternas, pecioladas, inteiras ou pinaticompostas com gavinhas terminais. Capítulos heterógamos, radiados, raramente homógamos, discoides pedunculados ou sésseis solitários terminais. Invólucro campanulado; brácteas involucrais imbricadas, lanceoladas, multisseriadas, tomentosas ou glabras, às vezes esquarrosas. Receptáculo plano, glabro. Flores centrais longas, bilabiadas ou raramente líguladas, amarelas; flores radiais com limbo expandido, amarelas, laranjas, vermelhas, magentas ou alvas; anteras longo-exsertas, apêndice apical obtuso, caudadas, lisa ou laciniada; ramos do estilete curtos, obtusos, dorsalmente papilosos. Cipsela cilíndrica ou oblonga, glabra. Papilho unisseriado com cerdas plumosas, creme ou alvo.

Mutisia speciosa Aiton ex Hook. Bot. Mag. 54: 2705. 1827.

Arbusto volúvel; ramos angulosos, alvotomentosos. Folhas alternas, pinatissectas, raque $3-4,5 \mathrm{~cm}$, vilosa, terminada em gavinha trífida, folíolos de 4-6 pares alternos, 2-4 × 0,8-1 cm, ápice agudo, margem inteira, base cuneiforme, faces adaxial glabra, abaxial alvo-lanuginosa. Capítulos radiados, pedunculados; invólucro 40-45 $\mathrm{mm}$; brácteas involucrais 5-7 séries, gradualmente maiores, glabras ou apenas com ápice alvo-lanoso, levemente esquarrosas. Flores
60-70, dimorfas: radiais pistiladas, bilabiadas, 45-50 mm, limbo externo expandido, magenta; flores centrais hermafroditas, bilabiadas, 25-30 $\mathrm{mm}$, limbo externo revoluto, amarelas. Cipsela 4-5 mm compr., oblonga, levemente costada. Papilho 30-35 mm compr., alvo.

Material examinado: Ouro Preto, PEI, Trilha da Estrada de Cima, 28.IX.2005, fl. e fr., G.S.S. Almeida et al. 129 (VIC). Mariana, PEI, Trilha da Serrinha, 11.XII.2006, fl. e fr., G.S.S. Almeida et al. 605 (VIC).

Mutisia speciosa está amplamente distribuída no Brasil nos estados das Regiões Sudeste e Sul (Nakajima et al. 2010). No PEI a espécie foi coletada na borda da trilha em capão de mata de encosta seca, em altitude superior a $1.300 \mathrm{~m}$. Distingue-se de M. coccinea St-Hil., espécie mais próxima, pelas folhas com face adaxial glabra e abaxial lanuginosa e flores radiais magenta.

Richterago Kuntze, Revis. Gen. P1. 1: 360. 1891. Subarbustos ou ervas, monóicos. Folhas rosulado-basais ou alternas, sésseis a curtopecioladas, face abaxial glanduloso-pontuada. Capítulos solitários ou dispostos em cimeiras paucicéfalas, raro multicéfalas, radiados ou discóides. Invólucro campanulado, brácteas involucrais 5-9 séries, imbricadas. Receptáculo alveolado, glabro. Flores alvas ou lilases, do raio quando presentes, unisseriadas, bilabiadas $(3+2$, $3+1$ ou $4+1$ ), abaxialmente glandulosa; flores do disco tubulosas, pentalobadas com lobos revolutos, abaxialmente glandulosa; anteras oblongas, apêndice apical apiculado, basal laciniado; estilete obtuso, glabro. Cipsela cilíndrica, tomentosa ou velutina. Papilho cerdoso, unisseriado, basalmente conado em anel, alvo ou creme.

\section{Chave para as espécies de Richterago do Parque Estadual do Itacolomi}

1. Subarbustos; folhas alternas; capítulos discóides.

2. Cimeiras multicéfalas; brácteas involucrais $6-8$ séries; flores lilases a róseas

2. Cimeiras paucicéfalas; brácteas involucrais $4-5$ séries; flores alvas Richterago amplexifolia

1. Ervas; folhas rosulado-basais; capítulos radiados.

3. Inflorescência monocéfala.

4. Folhas eretas, face adaxial ferrugíneo-tomentosa a glabrescente, margem denteada apenas na metade superior Richterago polymorpha

4. Folhas patentes, face adaxial cinéreo-estrigosa, margem denteada ........ Richterago radiata

3. Inflorescência paucicéfala.

5. Folhas longo-pecioladas $(10-50 \mathrm{~mm})$; flores do raio caducas

5. Folhas sésseis a curto-pecioladas $(2-5 \mathrm{~mm})$; flores do raio persistentes Richterago petiolata Richterago campestris 
Richterago amplexifolia (Gardner) Kuntze, Revis. Gen. P1. 1:360. 1891.

Fig. 3a-f

Subarbusto ca. 0,8 $\mathrm{m}$ alt., ramo folhoso na porção inferior. Folhas alternas, superiores sésseis, inferiores pecioladas, pecíolo expandido lateralmente, constituindo bainha, ambas oblongolanceoladas, 1,5-10 × 1-5 cm, ápice mucronulado, margem denteada, base amplexicaule, cordada ou obtusa, face adaxial glabra, nervuras tomentosas, face abaxial velutino-tomentosa a glabrescente, glandulosa. Capítulos subsséseis, em cimeira multicéfala, discóides. Invólucro 12-15 mm compr.; brácteas involucrais 6-8 séries, lanceoladas, ápice acuminado, velutinas a glabrescentes, glandulosas. Flores 40-50, hermafroditas, tubulosas, 10-11 mm, lilases a róseas, glandulosas. Cipsela 1,5-2 mm compr., albo-serícea, glandulosa. Papilho 7,5-8 mm compr., creme.

Material examinado: Ouro Preto, PEI, Trilha da Lagoa Seca, 14.XI.2005, fl. e fr., G.S.S. Almeida et al. 140 (VIC); Trilha do Pico, 17.IV.2006, fl. e fr., G.S.S. Almeida et al. 367 (VIC); Trilha do Morro do Cachorro, 27.VI.2006, fl. e fr., G.S.S. Almeida et al. 458 (VIC);

Richterago amplexifolia é endêmica do Brasil, encontra-se distribuída nos estados de Mato Grosso e Minas Gerais e Distrito Federal (Roque \& Pirani 2001). No PEI esta espécie foi coletada em afloramentos rochosos e em campos graminosos secos.

Roque \& Pirani (2001) na descrição do gênero Richterago, citam a presença de pecíolo com base expandida lateralmente. Este tipo de pecíolo é bem evidente nas folhas inferiores de $R$. amplexifolia, na qual o pecíolo apresenta-se completamente expandido lateralmente, envolvendo o caule, constituindo uma bainha (Fig. 34). Algumas vezes, esta bainha é confundida com a base da folha, que incorretamente é descrita como decorrente. A denominação, bainha é pela primeira vez usada para esta estrutura, no entanto morfologicamente é a mais correta e elucidativa.

Distingue-se de $R$. discoidea (Less) Cabrera, espécie mais próxima, pelos capítulos subsésseis e pelas brácteas involucrais densamente lanosas.

Richterago campestris Roque \& J.N. Nakaj., Kew Bull. 5(3): 698. 2001.

Fig. 3g-j

Erva ca. $0,5 \mathrm{~m}$ alt.; ramos densamente lanosos. Folhas rosulado-basais, sésseis a curtopecioladas, pecíolo lateralmente expandido, lanoso, oblongo-lanceoladas, 11-13 × 2,8-3,5 $\mathrm{cm}$, ápice apiculado, margem esparsamente denticulada, base atenuada, face adaxial glabra, abaxial setosa a glabrescente, glandulosa. Capítulos em inflorescência paucicéfala (2-3), radiados. Invólucro 12-20 mm compr.; brácteas involucrais 7-9 séries, linear-lanceoladas, ápice acuminado, estrigosas, glandulosas. Flores 70-80, alvas: radiais pistiladas, bilabiadas $(3+2), 12-13$ $\mathrm{mm}$, esparsamente glandulosas; flores do disco hermafroditas, tubulosas, 10-12 mm, glandulosas, lobos revolutos com ápice papiloso, glanduloso. Cipsela 3,5-4 mm compr., densamente albotomentosa. Papilho 8-9 mm compr., creme.

Material examinado: Mariana, PEI, Trilha do Sertão, 2.XII.2005, fl. e fr., G.S.S. Almeida et al. 197 (VIC).

Richterago campestris é endêmica de Minas Gerais, ocorrendo em campos rupestres na Serra da Canastra e outras localidades disjuntas do sudeste do estado (Roque \& Nakajima 2001). No PEI foi coletada em campos graminosos úmidos. Tem como espécies mais próximas $R$. angustifolia (Gardner) Roque, da qual se diferencia pelas folhas planas, não involutas e $R$. riparia Roque, da qual se diferencia por apresentar folhas oblongo-lanceoladas.

Richterago discoidea (Less.) Kuntze, Revis. Gen. P1. 1:360.1891.

Fig. 3k-n

Subarbusto ca. $0,8 \mathrm{~m}$ alt.; ramos tomentosos. Folhas alternas, poucas: inferiores curto pecioladas, elípticas, 7-12,5 × 2,5-3,5 cm, ápice obtuso, às vezes agudo, margem denticulada, base obtusa, face adaxial glabra, abaxial setosa a glabrescente, densamente glandulosa; superiores semi-amplexicaules, elípticas ou ovadas, 6-12 $\times$ 2,5-4 cm, densamente tomentosas em ambas as faces. Capítulos em cimeira paucicéfala, discóides. Invólucro 10-12 mm compr.; brácteas involucrais 4-5 séries, lanceoladas, tomentosas, glandulosas. Flores 35-40, hermafroditas, tubulosas, $8-10 \mathrm{~mm}$, lobos glandulosos, ápice penicelado, alvas. Cipsela 2,5-3 mm compr., alvo-setosa. Papilho 7-8 mm compr., creme.

Material examinado: Ouro Preto, PEI, Trilha do Calais, 27.IX.2005, fl. e fr., G.S.S. Almeida et al. 110 (VIC); Trilha da Lagoa Seca, 27.XI.2006, fl. e fr., G.S.S. Almeida et al. 566 (VIC);

Richterago discoidea é endêmica do Brasil ocorrendo nos estados de Minas Gerais, Mato Grosso e Bahia (Hind 2003). No PEI foi coletada em afloramentos rochosos e em campos graminosos úmidos. Distingue-se da espécie mais próxima $R$. amplexifolia, pelos capítulos com menor número de brácteas involucrais e pelas flores alvas. 


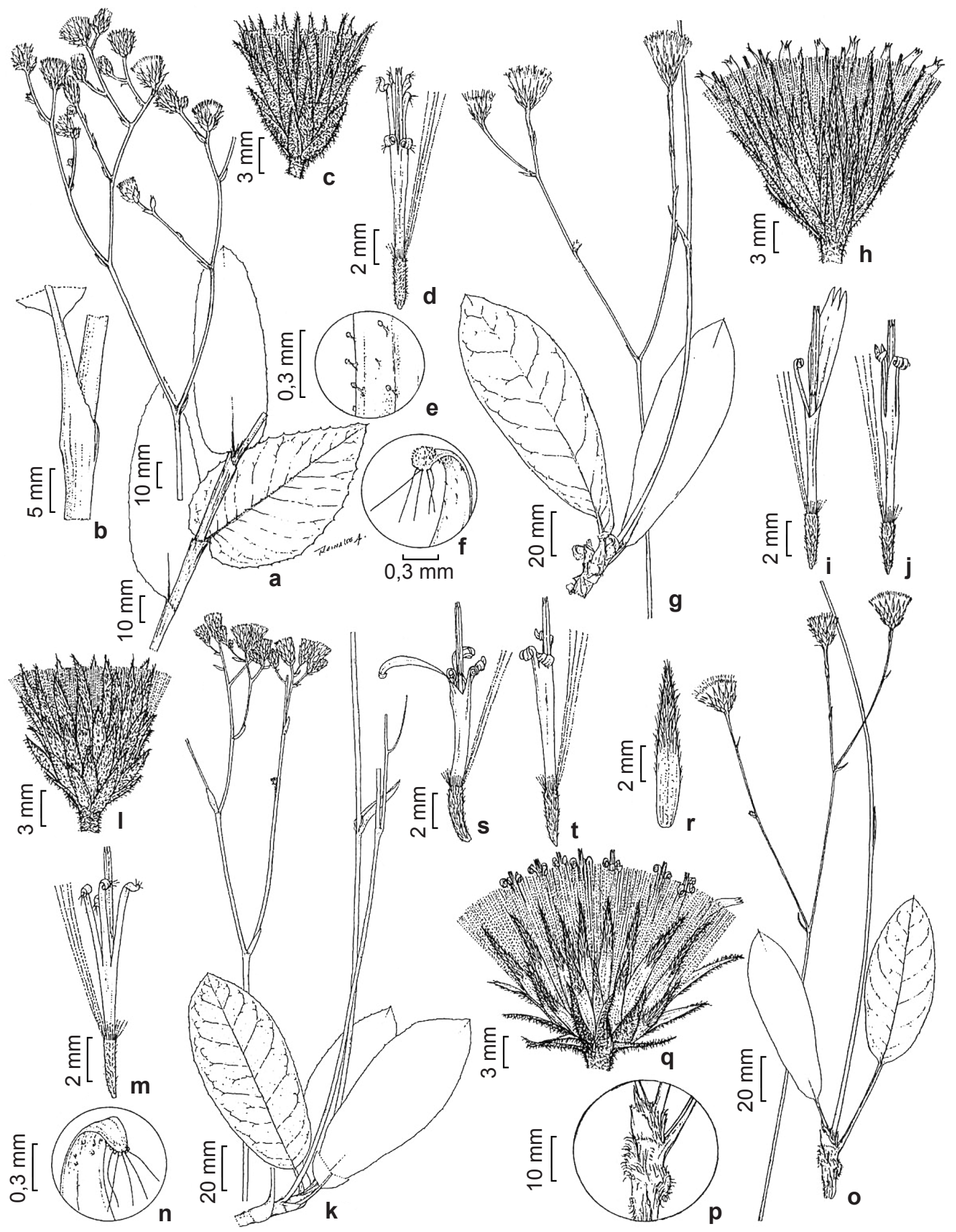

Figuras 3 - a-f. Richterago amplexifolia - a. hábito; b. bainha; c. capítulo; d. flor; e. corola; f. lobo da corola (Almeida et al. 367). g-j. Richterago campestris - g. hábito; h. capítulo; i. flor do raio; j. flor do disco (Almeida et al. 197). k-n. Richterago discoidea - k. hábito; 1. capítulo.; m. flor; n. lobo da corola (Almeida et al. 110). o-t. Richterago petiolata - o. hábito; p. base do pecíolo; q. capítulo; r. bráctea involucral; s. flor do raio; t. flor do disco (Almeida et al. 213). Figuras 3 - a-f. Richterago amplexifolia - a. habit; b. sheath; c. head; d. floret; e. corolla; f. corolla lobe (Almeida et al. 367). g-j. Richterago campestris - g. habit; h. head; i. ray floret; j. disc floret (Almeida et al. 197). k-n. Richterago discoidea - k. habit; 1. head.; m. floret; n. corolla lobe(Almeida et al. 110). o-t. Richterago petiolata - o. habit; p. base of the petiole; q. head; r. involucral bract; s. ray floret; t. disc floret (Almeida et al. 213). 
Richterago petiolata Roque \& J. N. Nakaj., Kew Bull. 56(3):700. 2001.

Fig. 3o-t

Erva ca. $0,9 \mathrm{~m}$ alt. Folhas rosulado-basais, longo-pecioladas, pecíolo $10-50 \mathrm{~mm}$, lateralmente expandido, dourado-lanoso na base, elíptica, 8-14× 2,5-3,7 cm, ápice apiculado, margem denticulada, base atenuada, face adaxial estrigosa a glabrescente, lustrosa, abaxial glanduloso-pontuada, nervuras vilosas. Capítulos em inflorescência paucicéfala (2-5), radiado. Invólucro 13-15 mm compr.; brácteas involucrais 8-10 séries, lanceoladas, ápice acuminado, margem ciliada, dorso gríseotomentoso, glanduloso-pontuadas. Flores 7-80, alvas, tubulosas, 10-12 $\mathrm{mm}$, gibosas, lobos revolutos, ápice espessado, glanduloso. Flores do raio caducas, com limbo irregular. Cipsela $2-3 \mathrm{~mm}$ compr., gríseo-setosa. Papilho $8-9 \mathrm{~mm}$ compr., creme.

Material examinado: Ouro Preto, PEI, Trilha do Pico, 3.XII.2005, fl. e fr., G.S.S. Almeida et al. 213 (VIC).

Richterago petiolata é endêmica do Brasil com distribuição disjunta, conhecida apenas para Serra da Canastra (Minas Gerais) e Chapada dos Veadeiros (Goiás) (Roque \& Nakajima, 2001). A ocorrência de R. petiolata no PEI amplia sua área de distribuição geográfica, também para o Sul da Cadeia do Espinhaço. Distingue-se da espécie mais próxima $R$. polymorpha (Less.) Roque, pelas folhas longo-pecioladas e flores do raio persistentes e maiores que as flores do disco. Os exemplares de $R$. petiolata coletados no PEI, apresentaram 2-5 capítulos ordenados em cimeiras, sendo que Roque \& Nakajima (2001), citam para esta espécie 1-2 capítulos. Entretanto, tal variação é comum nas espécies do gênero em diferentes populações. Os materiais examinados apresentam capítulos com poucas flores do raio ou flores do raio ausentes, sendo característico de $R$. petiolata a presença de capítulo radiado com flores do raio caducas, pistiladas, bilabiadas ou com limbo de forma irregular e do mesmo tamanho das flores do disco.

Richterago polymorpha (Less.) Roque, Taxon 50(4): 1159. 2001.

Fig. 4a-e

Erva ca. $0,8 \mathrm{~m}$ alt. Folhas rosuladobasais, subsésseis, obovadas, $8-14 \times 2-2,5 \mathrm{~cm}$, ápice apiculado, margem levemente denteada na metade superior, base atenuada, face adaxial glabrescentes, ferrugíneo-tomentosa, face abaxial estrigosa, tricomas glandulares sésseis, amarelos. Capítulos em inflorescência monocéfala, radiados.
Invólucro 10-15 mm compr.; brácteas involucrais 5-7 séries, lanceoladas, ápice apiculado nas externas, agudo nas internas, seríceo-tomentosas a glabrescentes. Flores $120-150$, alvas: radiais pistiladas, bilabiadas $(3+1 ; 3+2), 13-14 \mathrm{~mm}$, glandulosas; flores do disco hermafroditas, tubulosas, $8-10 \mathrm{~mm}$, lobos revolutos, ápice espessado, papiloso. Cipsela 2,5-3 mm compr., alvo-velutina. Papilho 7,5-8 $\mathrm{mm}$ compr., cerdas estrigosas, creme.

Material examinado: Ouro Preto, PEI, Trilha da Lagoa Seca, 22.VIII.2005, fl.e fr., G.S.S. Almeida et al. 50 (VIC).

Richterago polymorpha é endêmica do estado de Minas Gerais (Roque 1997). No PEI foi coletada em campo graminoso aberto em solo areno-pedregoso. Distingue-se de $R$. radiata (Vell.) Roque, espécie mais próxima, pelas folhas eretas com indumento ferrugíneo-tomentoso, quando jovens e com tricomas glandulares sésseis, amarelos.

Richterago radiata (Vell.) Roque, Taxon 50(4): 1159. 2001.

Fig. 4f-j

Erva ca. 0,6 m alt. Folhas rosulado-basais, patentes, obovadas, 4-7,5 × 3-5 cm, ápice obtuso, margem denteada, base levemente atenuada, lateralmente expandida, faces adaxial estrigosa, abaxial tomentosa a glabrescentes. Capítulos em inflorescência monocéfala, radiados, pedúnculo lanoso. Invólucro 12-15 mm compr.; brácteas involucrais 6-8 séries, lanceoladas, ápice apiculado, margem ciliada, tomentosas. Flores 200-220, alvas: radiais pistiladas, bilabiadas $(3+2), 13-16$ $\mathrm{mm}$, lobos internos eretos, glandulosas; flores do disco tubulosas, $10-12 \mathrm{~mm}$, lobos revolutos, ápice espessado, papiloso. Cipsela 4,5-5 $\mathrm{mm}$ compr., alvo-velutina. Papilho 9-10 mm compr., cerdas estrigosas, creme.

Material examinado: Ouro Preto, PEI, Trilha da Lagoa Seca, 14.XI.2005, fl.e fr., G.S.S. Almeida et al. 145 (VIC); Trilha do Pico, 28.I.2006, fl. e fr., G.S.S. Almeida et al. 283 (VIC); Trilha do Calais, 29.I.2007, fl. e fr., Almeida et al. 639 (VIC).

Richterago radiata é endêmica do Brasil apresentando distribuição geográfica ampla em relação às outras espécies do gênero, ocorrendo em Minas Gerais, São Paulo, Paraná e Goiás (Roque 1997). No PEI foi coletada em campo graminoso em solo areno-pedregoso. Distingue-se de $R$. polymorpha (Less.) Roque, espécie mais próxima, pelas folhas patentes com indumento cinéreoestrigoso e margem denteada. 


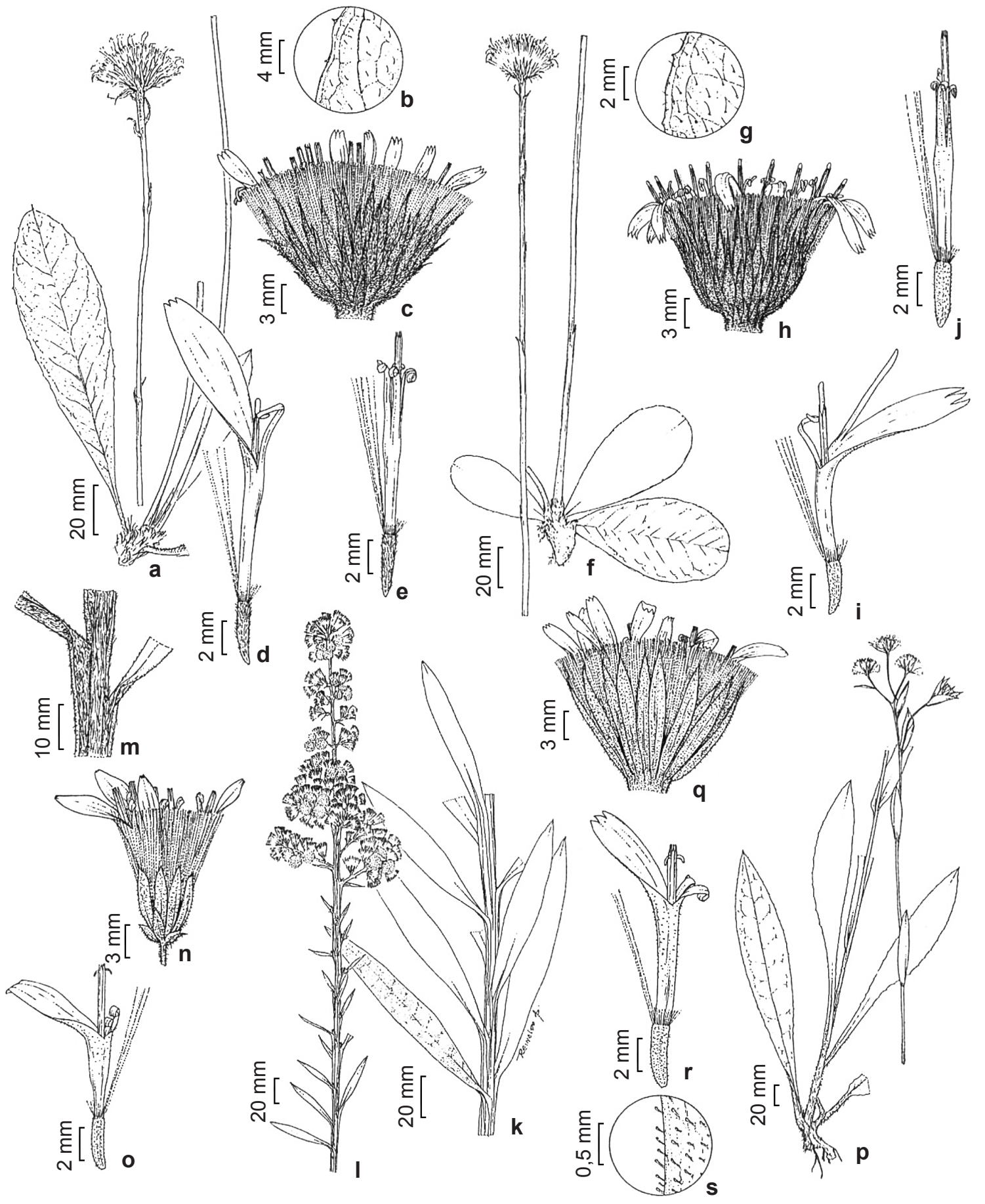

Figuras 4 -a-e. Richterago polymorpha - a. hábito; b. margem foliar; c. capitulo; d. flor do raio; e. flor do disco (Almeida et al. 50). f-j. Richterago radiata - f. hábito; g. margem foliar; h. capítulo; i. flor do raio. j. flor do disco (Almeida et al. 283). k-o. Trixis nobilis - k. base do ramo; l. ápice do ramo; m. base da folha; n. capítulo; o. flor (Almeida et al. 369). p-s. Trixis lessingii - p. hábito; q. capítulo. r. flor. s. tubo da corola (Almeida et al. 642).

Figures 4 - a-e. Richterago polymorpha - a. habit; b. leaf margin; c. head; d. ray floret; e. disc floret (Almeida et al. 50). f-j. Richterago radiata -f. habit; g. leaf margin; h. head; i. ray floret. j. disc floret (Almeida et al. 283). k-o. Trixis nobilis - k. branch base; 1. branch apex ; m. base of the leaf; $n$. head; o. floret (Almeida et al. 369). p-s. Trixis lessingii - p. habit; q. head. r. floret. s. tube of the corolla (Almeida et al. 642). 
Trixis P. Browne., Civ. Nat. Hist. Jamaica: 312. 1756.

Ervas ou arbustos, monóicos. Folhas alternas, às vezes, as inferiores adensadas em roseta basal, as superiores decorrentes, densamente pubescentes. Capítulos terminais dispostos em pseudo-espigas ou pseudocorimbos; discóides. Invólucro campanulado ou hemisférico; brácteas involucrais 2-3 séries.
Receptáculo plano, alveolado, piloso. Flores hermafroditas, bilabiadas $(3+2)$, amarelas ou alaranjadas, glandulosas, tubo internamente viloso; anteras alongadas, apêndice do conectivo oblongo, base longo-caudada ramos do estilete truncados, penicelados no ápice, papilosos. Cipsela cilíndrica, 5-costada, atenuada em direção ao ápice, híspido-glandulosa. Papilho cerdoso, livre, persistente ou caduco, creme.

\section{Chave para as espécies de Trixis do Parque Estadual do Itacolomi}

1. Folhas rosulado-basais e distribuídas esparsamente nos ramos, espatuladas; papilho persistente.

2. Folhas semi-amplexicaules; flores 35-50, alaranjadas ....................................... Trixis lessingii

2'. Folhas basais longo-atenuadas formando pseudopecíolos, flores 28-30, amarelo-claras

$$
\text { Folhas basais longo-atenuadas formando pseudopeciolos, flores } 28-30 \text {, amarelo-claras ............ }
$$

1'. Folhas não rosuladas, elíptico-lanceoladas; papilho caduco. Trixis nobilis

Trixis glaziovii Baker, Fl. bras.,6(3):391. 1884.

Erva ca. 0,4 m alt.; ramos alados, alas 1-3 $\mathrm{mm}$, ferrugíneo-tomentosas. Folhas inferiores, rosulado-basais, espatuladas, $19-25 \times 2-4$ $\mathrm{cm}$, ápice obtuso, margem denticulada, base longo-atenuada formando pseudopecíolo, estrigosas; superiores esparsas, entrenós 10-15 $\mathrm{cm}$, espatuladas, $10-15 \times 2-3,5 \mathrm{~cm}$, ápice mucronulado, margem levemente denticulada, base longo-decorrente, faces adaxial glandulosotomentosa, abaxial híspida. Capítulos em pseudocorimbos paucicéfalos. Invólucro 9-10 $\mathrm{mm}$ compr.; hemisférico, brácteas involucrais 2 séries, lanceoladas, ápice agudo, margem ciliada, seríceo-ferrugíneas. Flores 28-30, amareloclaras, 8-10 mm, lábio externo tridentado, ápice setoso, papiloso, lábio interno revoluto, tubo da corola glanduloso. Cipsela 4,5-5 $\mathrm{mm}$ compr. Papilho 8-9 mm compr., com cerdas unisseriadas, acastanhadas, persistentes.

Material examinado: Ouro Preto, PEI, Trilha da Lagoa Seca, 29.I.2006, fl. e fr., G.S.S. Almeida et al. 249 (VIC).

Trixis glaziovii é endêmica do Brasil ocorrendo nos estados de Minas Gerais, Rio de Janeiro, São Paulo e Paraná; crescendo em planícies elevadas acima de $600 \mathrm{~m}$ de altitude em lugares abertos e úmidos (Katinas 1996). No PEI foi coletada em campo graminoso úmido a ca. $1500 \mathrm{~m}$ de altitude. Distingue-se da espécie mais próxima $T$. lessingii DC., pelas folhas longoatenuadas formando pseudopecíolo e pelas flores amarelo-claras.
Trixis lessingii DC., Prodr. 7: 70. 1838.

Fig. 4. p-s

Erva até $1,5 \mathrm{~m}$ de alt.; ramos alados, alas de 1-3 mm, vilosos. Folhas inferiores, rosulado-basais, espatuladas, $25-32 \times 3-4,5 \mathrm{~cm}$, superiores, semi-amplexicaules, oblongas, 5-8 $\times$ $1,5-3 \mathrm{~cm}$, ápice acuminado, margem sinuosa, base auriculada, ambas as faces estrigosas. Capítulos em pseudocorimbos terminais. Invólucro 10-15 mm compr.; hemisférico, brácteas involucrais 2 séries, lanceoladas, ápice agudo, velutinas. Flores 35-50, alaranjadas, $12-13 \mathrm{~mm}$, lábio externo tridentado, lábio interno revoluto, tubo da corola com tricomas glandulares castanhos e tricomas setosos alvos. Cipsela 6-7 mm compr. Papilho 7-8 mm compr., cerdas uniseriadas, persistentes.

Material examinado: Ouro Preto, PEI, Trilha do Tesoureiro, 28.IX.2005, fl. e fr., G.S.S. Almeida et al. 126 (VIC); Trilha do Tesoureiro, 18.I.2007, fl. e fr., G.S.S. Almeida et al. 642 (VIC).

Trixis lessingi é endêmica do Brasil sendo encontrada nos estados de Minas Gerais, São Paulo, Rio de Janeiro, Paraná, Santa Catarina e Rio Grande do Sul (Katinas 1996). No PEI a espécie foi coletada em campos úmidos, próximo a cursos d'água. Distingue-se de T. glaziovii, espécie mais próxima, pelas folhas amplexicaules e flores alaranjadas.

Trixis nobilis (Vell.) Katinas, Darwiniana 34(1-4): 74. 1996.

Fig. $4 \mathrm{k}-\mathrm{O}$

Subarbusto ca. $0,8 \mathrm{~m}$ alt.; caule estriado, alado, alas 2-4 mm, densamente viloso-ferrugíneas. Folhas alternas, sésseis, elíptico-lanceoladas, 
$7,5-15 \times 0,8-1,8 \mathrm{~cm}$, ápice agudo, margem crenada, base decorrente, faces adaxial estrigosa, abaxial alva ou ferrugíneo-tomentosa. Capítulos em pseudoespigas densas. Invólucro $8-10 \mathrm{~mm}$ compr.; campanulado, brácteas involucrais 2 séries, lanceoladas, tomentosas, glanduloso-pontuadas. Flores 8-15, amarelas, 8-9 mm, lábio exterior e interior revoluto, tubo da corola glabro. Cipsela 2,5-5 mm compr. Papilho 5-9 $\mathrm{mm}$ compr., bisseriado, cerdas palhetes, algumas com ápice vináceo, caducas.

Material examinado: Ouro Preto, PEI, Trilha da Estrada de Cima, 28.IX.2005, fl. e fr., G.S.S. Almeida et al. 136 (VIC); Trilha do Tesoureiro, 15.III.2006, fl. e fr., G.S.S. Almeida et al. 340 (VIC); Trilha do Pico, 17.IV.2006, fl. e fr., G.S.S. Almeida et al. 369 (VIC).

Trixis nobilis é endêmica do Brasil sendo encontrada nos estados das Regiões Sul e Sudeste, além de Goiás e Distrito Federal, habitando solos secos, em lugares abertos, pedregosos e em áreas modificadas (Katinas 1996) No PEI foi coletada em áreas de grande influência antrópica. Distingue-se da espécie mais próxima $T$. verbascifolia (Gardner) Blanke, pelos capítulos ordenados em pseudoespigas; invólucro campanulado; brácteas involucrais em apenas 2 séries e papilho com cerdas bisseriadas.

\section{Agradecimentos}

À Universidade do Estado da Bahia (UNEB), a bolsa concedida à primeira autora; ao Instituto Estadual de Florestas (IEF), a estrutura física concedida; aos funcionários do PEI o valioso auxílio; ao Reinaldo A. Pinto, as ilustrações; aos companheiros de campo, a atenção; aos funcionários do VIC, o auxílio e presteza; aos curadores dos herbários visitados; aos revisores as valiosas sugestões.

\section{Referências}

Almeida, G.S.S. 2008. Asteraceae Dumort. nos campos rupestres do Parque Estadual do Itacolomi, Minas Gerais, Brasil. Tese de Doutorado. Universidade Federal de Viçosa, Viçosa. 365p.

Almeida, G.S.S \& Carvalho-Okano, R.M. 2010. Three new species of Eupatorieae (Compositae) from Brazil. Kew Bulletin 65: 255-261

Badini, J. 1939. Sobre a ocorrência de Plantas Novas em Ouro Preto. Revista Farmacêutica de Ouro Preto 1: 1-3.

Baker, J.G. 1884. Compositae-Mutisieae. In: Martius, C.F.P. von; Eichler, A.W. \& Urban, I. (eds.). Flora brasiliensis. Munchen, Wien, Leipzig. Vol. 6. Pp. 339-396.
Barroso, G.M.; Peixoto, A.L.; Cota, C.G.; Ichaso, C.L.F.; Guimarães, E.F. \& Lima, H.C. 1991. Sistemática das angiospermas do Brasil. $3^{\mathrm{a}}$ ed. Universidade Federal de Viçosa, Viçosa. 309p.

Benites,V.M.; Caiafa, A.N.; Mendonça, E.S.; Schaefer, C.E. \& Ker, J.C. 2003. Solos e vegetação nos Complexos Rupestres da Altitude da Mantiqueira e do Espinhaço. Revista Floresta e Ambiente 10: 76-85.

Brandão, M.; Gavilanes, M.L. \& Araújo, M.G. 1994. Aspectos físicos e botânicos de campos rupestres do estado de Minas Gerais. Daphne 4: 17-38.

Bremer, K. 1994. Asteraceae, cladistics and classification. Timber Press, Portland. 752p.

Bremer, K. \& Jansen, R.K. 1992. A new subfamily of Asteraceae. Annals of the Missouri Botanical Garden 79: 414-415.

Burkart, A. 1944. Estúdio del género de compuestas Chaptalia com especial referencia a las espécies Argentinas. Darwiniana 6: 505-595.

Cabrera, A.L. 1959. Revision del género Dasyphyllum (Compositae). Revista del Museo de La Plata 9: 20-100.

Cabrera, A.L. \& Klein, R.M. 1973. Compostas - Tribo Mutisieae. In: Reitz, P.R. (ed). Flora ilustrada catarinense. Herbário Barbosa Rodrigues, Itajaí. Pp. 12-124.

Costa, C.M.R.; Hermann, G.; Martins, C.S.; Lins, L.V. \& Lamas, I.R. 1998. Biodiversidade em Minas Gerais: um atlas para a sua conservação. 1998. Fundação Biodiversitas, Belo Horizonte. 222p.

Cronquist, A. 1981. An integrated system of classification of flowering plants. Columbia University Press, New York. 1262p.

Fidalgo, O. \& Bononi, V.L.R. 1984. Técnicas de coleta, preservação e herborização do material botânico. Instituto de Botânica, São Paulo. 62p.

Giulietti, A.M.; Menezes, N.L.; Pirani, J.R. \& Wanderley, M.G.L.1987. Flora da Serra do Cipó, MG: caracterização e lista das espécies. Boletim de Botânica da Universidade de São Paulo 9: 1-157.

Hind, D.J.N. 1995. Compositae. In: Stannard, B.L. (ed.). Pico das Almas - Chapada Diamantina, Bahia, Brazil. Royal Botanic Gardens, Kew. Pp. 175-278.

Hind, D.J.N. 2003. Flora de Grão Mogol, Minas Gerais. Parte I. Asteraceae. Boletim de Botânica da Universidade de São Paulo 21: 179-234.

Katinas, L. 1996. Revisión de las espécies sudamericanas del gênero Trixis (Asteraceae, Mutiseae). Darwiniana 34: 27-108.

Kadereit, J.W. \& Jeffrey, C. 2007. Floweing plants. Eudicots: Asterales. In: Kubtisck, K. (ed.). The families and genera of vascular plants. Vol. 8 . Springer. 636p.

Kim, H.; Loockerman, D.J. \& Jansen, R.K. 2002. Systematic omplications of $\mathrm{ndhF}$ sequence variation 
in the Mutisieae (Asteraceae). Systematic Botany 27: 598-609.

Leitão Filho, H.F.; Aranha, C. \& Bacchi, O. 1975. Plantas invasoras de culturas no estado de São Paulo. Vol. 2. Hucitec-Agiplan, São Paulo. 305p.

Lisboa, M.A. 1971. A flora de Ouro Preto. Revista da Escola de Minas 39: 1-10.

Viana, P.L. \& Lombardi, J.A. 2007. Florística e caracterização dos campos rupestres sobre canga na Serra da Calçada, Minas Gerais, Brasil. Rodriguésia 58: 159-177.

Messias, M.C.T.B.; Dias, S.J.L.; Roschel, M.B.; Souza, H.C.; Silva, J.L. \& Matos, A.V.M. 1997. Levantamento florístico das matas e distribuição de algumas espécies endêmicas da região na área do Parque do Itacolomi. Relatório técnico UFOP/ BIRD/IEF-PROFLORESTA, Universidade Federal de Ouro Preto, Ouro Preto. 151p.

Nakajima, J.; Loeuille, B.; Heiden, G.; Dematteis, M.; Hattori, E.K.O.; Magenta, M.; Ritter, M.R.; Mondin, C.A.; Roque, N.; Ferreira, S.C.; Teles, A.M.; Borges, R.A.X.; Monge, M.; Bringel Jr., J.B.A.; Oliveira, C.T.; Soares, P.N.; Almeida, G.; Schneider, A.; Sancho, G.; Saavedra, M.M.; Liro, R.M.; Souza-Buturi, F.O.; Pereira, A.C.M. \& Moraes, M.D. 2010. Asteraceae . In: Lista de espécies da flora do Brasil. Vol. 1. Jardim Botânico do Rio de Janeiro, Rio de Janeiro. Pp. 678-750.

Peron, M.V. 1989. Listagem preliminar da flora fanerogâmica dos campos rupestres do Parque Estadual do Itacolomi-Ouro Preto/Mariana, MG. Rodriguesia 67: 63-69.

Pruski, J.F. \& Sancho, G. 2004. Asteraceae. In: Smith, N. et al. (eds.). Flowering plants of the neotropics. Pinceton University Press, New, York. Pp.33-39.
Radford, A.E.; Dickison, W.C.; Massey, J.R. \& Bell, C.R. 1974. Vascular plant systematics. Harper \& Row, New York. 891p.

Roque, N. 1997. Areassessment of Actinoseris polymorpha (Less.) Cabrera (Compositae: Mutisieae) with a new combination. Kew Bulletin 52: 197-204.

Roque, N. 2005. A new species of Chaptalia (Compositae, Mutisieae) from Minas Gerais, Brasil. Kew Bulletin 60: 133-135.

Roque, N. \& Nakajima, J.N. 2001. Two new species of Richterago Kuntze emend. Roque (Asteraceae, Mutisieae) from Minas Gerais and Goias, Brazil. Kew Bulletin 56: 697-703.

Roque, N. \& Pirani, J.R. 1997. Flora da Serra do Cipó, Minas Gerais: Compositae - Barnadesieae e Mutisieae. Boletim de Botânica da Universidade de São Paulo 16: 151-185.

Roque, N. \& Pirani, J.R. 2001. Reinstatement of the name Richterago Kuntze and recircunscription of the genus to include species formely treated as Actinoseris (Endl.) Cabrera (Compositae, Mutisieae). Táxon 50: 1155-1160.

Sancho, G. 2000. Revisión y filogenia de la sección Moquiniastrun Cabrera del género Gochnatia Kunth (Asteraceae, Mutisieae). Fontqueria 54: 61-122.

Smith, N.; Mori, S.A.; Henderson, A.; Stevenson, D.W. \& Heald, S.V. 2004. Flowering plants of the Neotropics. Princeton University Press, Princeton. $616 \mathrm{p}$.

Zappi, D.C.; Lucas, E.; Stannard, B.L.; Lunghadha, E.N.; Pirani, J.R.; Queiroz, L.P.; Atkins, S.; Hind, N.; Giulietti, A.M.; Harley, R.M. \& Carvalho, A.M. 2003. Lista das plantas vasculares de Catolés, Chapada Diamantina, Bahia, Brasil. Boletim de Botânica da Universidade de São Paulo 21: 345-39 